\title{
A review on ecotoxic potential of pollutants in fish
}

\author{
Kirandeep Kaur* \\ Department of Zoology, Khalsa College, Amritsar-143005 (Punjab), India \\ Satinder Kaur \\ Department of Zoology, Khalsa College, Amritsar-143005 (Punjab), India \\ Arvinder Kaur \\ Department of Zoology, Guru Nanak Dev University, Amritsar-143005 (Punjab), India \\ *Corresponding author. E-mail: kkirandeep575@gmail.com
}

\begin{abstract}
Fishes in the aquatic food web are at the top of most aquatic food chains and form an important link in the aquatic-terrestrial food chain also. They are easily available in the wild, market, can be easily maintained in the laboratory and act as important models for indicating the outcome of exposure of human populations to toxic and genotoxic chemicals in drinking water. They respond to toxicants in a manner similar to higher vertebrates and metabolize and accumulate pollutants. Food is a major route for exposure of human populations to toxic chemicals in water so fish and shell fish have been recognized as major vectors for transfer of contaminants to humans, as these major sources of protein in many countries, are often contaminated with high concentrations of pollutants. In living systems, these are biotransformed to various toxic derivatives which react with DNA and lead to tumour development are carcinogenic and/or mutagenic to life leading to the number of cancer cases. Epidemiological studies have revealed that workers in the dye industry had a higher incidence of urinary bladder tumours than that of the general population. Therefore, in the present review an attempt has been made to document the work done in past on the use of fishes for studying toxicological changes induced by pollutants. Actually, toxicity and genotoxicity of dyes in fish has not been much explored, therefore along with the few reports available on dyes, literature on toxicity and genotoxicity of other aquatic pollutants has also been reviewed in the present study.
\end{abstract}

Keywords: Toxicity, Genotoxicity, Micronucleus assay, Mutagenic, Nucleocellular abnormality assay.

\section{INTRODUCTION}

Aquatic ecosystems are of extreme importance for the world population, as these are used for domestic, agricultural, industrial as well as recreational activities. In return the aquatic bodies end up being the final destination of a large quantity of wastes from these sectors. Waste waters from dye manufacturing, paper, leather and textile industries bring tons of dyes into the aquifers, most of which are highly toxic to the flora and fauna of the receiving water bodies (McCarthy, 1997). As a result, various dyes are banned and maximum residue levels exist in Europe and USA, however, in several other countries of the world, these dyes are openly sold in the market without any information regarding their chemical nature, purity, toxicity and possible mutagenicity (Mathur et al., 2005). Unregulated use of dyes will therefore have grave consequences for human health and aquatic ecosystems in these countries. The aquatic environment is of primary concern because many a times these various toxic chemicals not only have

\section{Article Info}

DOI:10.31018/jans.v11i1.1948

Received: October 12, 2018

Revised: January 15, 2019

Accepted: January 30, 2019

\section{How to Cite}

Kaur, K. et al. (2019). A review on ecotoxic potential of pollutants in fish. Journal of Applied and Natural Science, 11(1): 48 $-53$

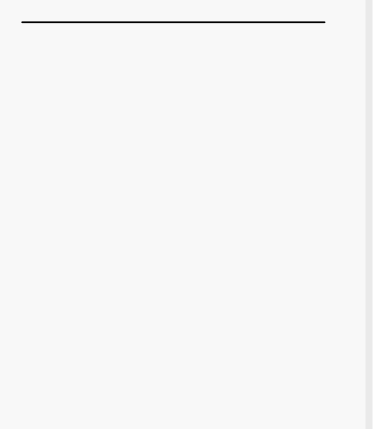

significant implications for long-term survival of natural populations of the organisms living therein but cause heritable mutations that may lead to loss of the total genetic diversity of an ecosystem. Of all the aquatic organisms fish have become vulnerable indicators for evaluation of the effects of such noxious compounds (Kaur and Dua, 2015) as these are the ultimate sufferers of pollution and form an important link in the food chain of humans.

By virtue of their high reactivity, dyes and other genotoxins contribute to structural modifications in the DNA of fish which then become the underlying cause of metabolic dysfunction and death. These disturbances being irreversible are transmitted to the future generations, have long lasting effects and appear even at those levels of toxins which are otherwise safe for survival. Estimation of DNA damage (genotoxicity) therefore helps to ascertain ill effects of even minute doses of toxicants which otherwise do not cause immediate mortality (Tchounwou et al., 2012). Technique like micronucleus/ nucleocellular abnormality assay is com- 
monly used for this purpose and provide information about chromosomal/DNA damage. Chromosomal fragments or whole chromosomes with damaged or no centromere form micronuclei in cells and the changes in morphology of cell are also an outcome of alterations in the genetic material, so their collective frequency highlights genotoxic potential of a pollutant. There is always a tissue specific variation in susceptibility and response to pollutants therefore multiple nucleocellular abnormalities and multiple tissue analysis is preferred nowadays as it gives better results (Reeves et al., 2008). Assessment of loss/ alteration of genetic material in the cell is done with the help of micronucleus /nucleocellular abnormality assay as it can detect even slightest damage to DNA in a variety of tissues and in a short span of time. Therefore, its results are being used nowadays as biomarkers (early signs of danger) for environmental biomonitoring and for developing control strategies and preventive measures (Market et al., 2003). The most important advantage of this technique is that size and number of chromosomes is not important and mitotic activity of cells is not required. So it can be easily used for fishes having a large no of small sized chromosomes. Actuallytoxicity and genotoxicity of dyes in fish has not been much explored, therefore along with the few available reports on dyes, literature on toxicity and genotoxicity of other aquatic pollutants has also been reviewed in the present manuscript. The aim of the present study is to review the information on 1) Toxicity of dyes, dye constituents and dye containing effluents, 2) Genotoxicity (Nucleo-Cellular Abnormality Assay).

Toxicity of dyes, dye constituents and dyes containing effluents: Toxicity is the level at which an organism can be harmed by a substance or it refers to the extent of harm to an organism whether it is an animal, bacteria or plant or substructure of an organism such ascell (cytotoxicity) or an organ (organotoxicity like hepatotoxicity for liver) and can be measured by its effect on the target. As organisms show differentresponses to same dose of a chemical, a population level is the measure of probabilities of results of sample individuals in a total sample population. Tonogai et al. (1979) revealed that acute toxicity of organic nitrogenous compounds and dyes to fish was due to their passage through cell membrane and accumulation in the body. They reported that Methylene Blue and Rose Bengal brought a rise in red blood cells (RBCs), had high affinity to gill and were responsible for death of fish by depressing the function of gill, and making the fish suffer from anoxemia. In 1989, Riva found that $48 \mathrm{~h} \mathrm{LC}_{50}$ of the metal and dye complex C.I Acid Violet 66 and the azo dye compound utilized in its synthesis for Oncorhynchus mykiss was 8.20 and $71.04 \mathrm{mg} / \mathrm{L}$ respectively. They suggested that the main effect was due to chromium (Cr III) in the dye complex. When Japanese medaka, Oryzias latipes was exposed to 2500 parts per million (ppm) of an azo compound, 3,3,4,4-tetrachlorobenzene in diet, the mortality of exposed medaka was significantly higher as compared to control group (Allison and Morita, 1995). The lethal concentration (at 50\% population level) of Malachite Green for Heteropneustus fossilis at different time intervals i.e. 24, 48, 72 and 96h were 5.6, 1.4, 1.25 and $1 \mathrm{mg} / \mathrm{L}$, respectively (Srivastava et al., 1995). Raizada and Rana (1998) reported Malachite Green to be very toxic to Clarias batrachus as its $96 \mathrm{~h} \mathrm{LC}_{50}$ value came to be $0.86 \mathrm{mg} / \mathrm{L}$. Toxicity of Malachite Green to various species of fishes has been reported to increase with concentration, exposure time and temperature (Srivastava et al., 2004).

Oreochromis mossambicus responded to even very low concentrations of aniline, although $96 \mathrm{~h}$ $\mathrm{LC}_{50}$ value of aniline for fish was $69.4 \mathrm{mg} / \mathrm{L}$ but outdoor bioassay with tilapia showed that even $0.02 \mathrm{mg} / \mathrm{L}$ aniline reduced fish yield, specific growth rate and food conversion efficiency (Bhunia et al., 2003). Sharma et al. (2005) reported that $96 \mathrm{~h}$ LC $_{50}$ value of Methyl Red was 27.2 ppm for Poecilia reticulata. White et al.(2012) reported that Malachite Green Oxalate was more toxic to the embryos and larvae of zebrafish, Danio rerio $\left(\mathrm{LC}_{50}=0.067\right.$ and $0.057 \mu \mathrm{M}$ respectively) than Malachite Green Chloride $\left(\mathrm{LC}_{50}=0.116\right.$ and $0.103 \mu \mathrm{M}$ respectively).

Kundu et al. (1989) calculated 96h LC $_{50}$ value of dyeing and printing industry effluent for Periophtalmus diper to be $1.72 \mathrm{mg} / \mathrm{L}$ and observed this effluent to be an active inhibitor of various biocatalysts such as membrane bound ATPases in fish. 96h LC50 value of paper and pulp mill effluent to fingerlings of O.mossambicus was reported by Varadaraj and Subramanian (1991) to be $6 \%$. 96h LC 50 values for Labeo rohita were $7.2 \mathrm{mg} / \mathrm{L}$ for the textile dyes industry effluent and $0.2 \mathrm{mg} / \mathrm{L}$ for the tannery effluent, showing that the latter was more toxic to this fish. Both these effluents containing unbound dyes and a variety of chemicals caused considerable fish mortality (Rana and Raizada, 1999). The 24, 48, 72 and $96 \mathrm{~h}$ LC $_{50}$ values of paper mill effluent were found at 11, 10.5, 10.1 and $9.5 \%$ respectively in Rasbora daniconius (Pathan et al.2009). Olubukola and Victor (2012), reported that $96 \mathrm{~h} \mathrm{LC50}$ of food and beverage industry effluents for Clarias gariepinus was $52.81 \%$.

The median effective concentration $\left(\mathrm{EC}_{50}\right)$ of henna $(100,200$ and $275 \mu \mathrm{M})$ to Zebrafish (D. rerio) was found to be $140.76 \mu \mathrm{M}$ for $96 \mathrm{~h}$ post fertilized embryo by Manjunatha et al. (2014). The 96h LC 50 value of the contaminated water of Tung Dhab Drain, Amritsar, India was found to be $44.25 \%$ for the fingerlings of $L$. rohita by Kaur and Dua (2014). The 96h LC50 values for the various efflu- 
ents from the dye or dye using industries have been reported to be $20 \%$ in L. rohita (Muley et al. 2007), $513 \mathrm{mg} / \mathrm{L}$ for C. gariepinus (Ogaliet al., 2007), 35\% for Clarias lazera (Abdel-Moneimet al., 2008), $44.4 \pm 2.2 \%$ in Mystus vittatus (Mishra et al., 2011), $63 \mathrm{ml} / \mathrm{L}$ for C. gariepinus (Ukagwuet al., 2012), 48.97\% for Cirrhinus mrigala (Kaur et al., 2013), 39.726\% in Poecilia recticula (Selvaraj et al., 2015), $6.5 \%$ in Clarias garieipinus (Babatunde and Aminu, 2017). Sani et al. (2018) focused on four selected commercial dyesand observed that the LC50 of the various dyes on the test animals specified blue and yellow dyes to be highly toxic having the least LC50 value ( 0 and $0.95 \mu \mathrm{g} / \mathrm{ml}$ ) then red, with orange being the least toxic having the highest LC50 value (21.5 and $343.1 \mu \mathrm{g} / \mathrm{ml}$ ).

Genotoxicity: Earlier toxicology studies were confined to the effect of a variety of industrial pollutants on survival and some physiological parameters in fish but gradually genotoxicity gained more popularity and importance. Evaluation of cytogenetic damage in fish actually helps us to evaluate toxicity of minute quantities of pollutants in aquatic ecosystems, especially in situations when there is no mortality (Al-Sabti, 2000). Genotoxicity of contaminated water is generally studied by means of standard in vitro and in situ genotoxicity experiments. Micronucleus assay is a very simple, sensitive and can be used as genotoxic bioassay for monitoring toxicants in the environment in such situations (Osman, 2014).

Nucleo-cellular abnormality assay (NCAA): One of the most promising test is analysis of micronuclei (MN) and nucleo cellular abnormalities in RBCs of fish. This test has become an authentic index of cytogenetic damage over the past thirty years (Fenech et al., 2003) and gives reliable results for even complex mixtures. Analysis of cytogenetic damage in fish is not only useful for evaluation of selected genotoxic agent in the laboratory but also helps in detection of genotoxins present in various aquatic ecosystems. As response of fish to xenobiotics is same like mammals, they can be used to test the possible effectof genotoxins on man (Tlili et al., 2009). Several studiesare there reporting $\mathrm{MN}$ frequency in peripheral erythrocytes of fish on exposure to variouspollutants under field and laboratory conditions.

Marlasca et al. (1992) reported a non significant elevation in erythrocyte MN frequency in rainbow trout (O. mykiss) after thirty days of exposure to three sublethal doses $(0.083,0.036$ and 0.250 respectively) of C.I. Acid Violet 66 and Acid Red 217. Al-Sabti (2000), exposed prussian carp, Carassius auratus gibelio to 1,5 and $10 \mathrm{mg} / \mathrm{L}$ chlorotriazine Reactive Azo Red 120 (AR-120) for three, six and nine days andobserved that $M N$ augmented in a dose-dependent as well as in a time-dependent mannerin comparison to negative (tap water) and positive (10 ppm benzene) control group. His study revealed the genotoxicity of this dye and he suggested that more studies should be done on other dyes and some other lethal industrial pollutantsrelease in water ecosystems, using fish as abio-indicator. Mallaet al. (2011), observed asignificant increase inthe frequency of $\mathrm{MN}$ in the kidney and peripheral blood erythrocytes of H.fossilis on the fifteenth day of exposure to synthetic sindoor (50, 100,500, 1000 and 2000 ppm). Their results revealed that the synthetic sindoor available in the market is a possibleclastogen at high concentrations.Kaur and Dua (2016) observed a significant rise over control in the frequency of $\mathrm{MN}$ and $\mathrm{BN}$ in the liver cells in comparison to gill and erythrocytes of Labeo rohita after the effect of after durations of 15,30 and 60 days exposure to municipal wastewater of Tung Dhab drain $(17.7,26.6$ and $35.4 \%)$.

Exposure of eastern mud minnow, Umbra pygmea to $8-20 \mathrm{mg} / \mathrm{L}$ of ethyl methane sulphonate (EMS) for 2 days has been observed to induce nuclear abnormalities(NA) in the peripheral erythrocytes (Hooftman and de Raat, 1982). When Tilapia rendalli, Oreochromis niloticus and C. carpio, were exposed to four clastogens:bleomycin, cyclophosphamide (CP), 5-fluorouracil, and mitomycin $C$ by Grisolia and Cordeiro (2000) for thirty days, micronucleus frequencies induced by CP were observed to be significantly greater than the respective control samples for the three fish species throughout all treatment periods (two, seven, fourteen and thirty days). They noticed that $\mathrm{CP}$ was the most efficient clastogen and maximum sensitivity of T.rendalii to the clastogens was on the fourteenth day of the assessment. Palhares and Grisolia (2002) noticed non significant differences in the $\mathrm{MN}$ frequencies of gill and kidney erythrocytes in tilapia fish ( $T$. rendalli and $O$. niloticus), following mitomycin C $(2 \mathrm{mg} / \mathrm{Kg})$ and cyclophosphamide (40 $\mathrm{mg} / \mathrm{Kg}$ ) treatment for one, two, three, five, seven and fifteen days.

Talykina et al. (2003) exposed O. latipes to polychlorinated napthalene (PCN) formulations (Halowaxes 1014, 1031 and 1051) @ 0.3-30ng of PCN/embryoand tributyltin (TBT) @ 2.5fg-250pg of TBT/embryo, sampled on day $122 \pm 3$ and observed an increase in various types ofdeviations in the morphology of interphase nuclei of erythrocytes i.e.MN, split of nuclei into two equal or irregular parts and diverse stages of invaginations in the nuclei. They concluded that polychlorinated napthalenes caused genotoxicity while amitotic effect was caused by TBT.

When common carp (C.carpio), Prussian carp (C. auratusgibelio) and Peppered cory (Corydoras paleatus) were exposed to different doses of cadmium (0.005-0.1 mg/L) and copper (0.01-0.25 $\mathrm{mg} / \mathrm{L}$ ) and hexavalent chromium (5 $\mathrm{mg} / \mathrm{L})$ as a positive control for twenty one days. Frequencies 
of $\mathrm{MN}$ and binuclei (BN) were observed to increase significantly in peripheral red blood cells, epithelial cells of gill and liver cells. The tissues exhibited differential sensitivity to the heavy metal treatment, as the gill and liver cells showed high frequencies of $\mathrm{MN}$ and BNthan peripheral blood erythrocytes (Cavaset al., 2005).

Carla et al. (2008) reported that $10 \mu \mathrm{l} / \mathrm{L}$ and $16 \mu \mathrm{l} / \mathrm{L}$ nonylphenol ethoxylate (NPE) resulted in statistically significant increase in notched nuclei in $O$. niloticus, in comparison to $1 \mu \mathrm{L} \mathrm{NPE} / \mathrm{L}$ and control $(p<0.05)$ after $72 \mathrm{~h}$ exposure. Normannet al. (2008), observed rise in the MN frequency in the erythrocytes of armored cat fishes, Hypostomus plectomus on exposure to $12 \mathrm{mg} / \mathrm{L}$ potassium dichromate $(8.25 \pm 0.02 \%)$ in comparison to control $(0.75 \pm 0.03 \%)$. Rocha et al. (2011) exposed Nile tilapia (O. niloticus) to potassium dichromate (12 $\mathrm{mg} / \mathrm{L}$ ) via contaminated water and observed an increase in the frequency of MNto $1.0 \pm 1.15$ at $24 \mathrm{~h}$ and $2.43 \pm 0.98$ at $48 \mathrm{~h}$ over control (MN) in the peripheral blood. The frequency of nuclear morphological alterations in control, $24 \mathrm{~h}$ and $48 \mathrm{~h}$ group were $4.29 \pm 4.50,5.86 \pm 3.02$ and $11.0 \pm$ 3.74 , respectively. They observed significant differences among control and48h group only.A time dependent relative increase in $\mathrm{MN}$, apoptotic, binucleated and sticky adherent cells was noticed by Balakrishnan et al. (2014)in O. mossambicus after $24 \mathrm{~h}, 96 \mathrm{~h}$ and seven days exposure to 0.15 $\mathrm{mg} / \mathrm{L}$ nonylphenol.

Al-Sabtiet al. (1994) observed an augmentation in MN incidence in erythrocytes of $C$. auratus gibelio on exposure to various sublethal concentrations of Chromium [Cr (VI) $(25,50,100 \mathrm{ng} / \mathrm{ml} /$ seven days) and $\mathrm{Cr}$ (III) (50, 100, $200 \mathrm{ng} / \mathrm{ml} /$ sevendays)]. Nepomuceno et al. (1997) exposed C. carpio to 2 , 20 and $200 \mathrm{mg}$ metallic mercury/L water and found arisein the incidence of $\mathrm{MN}$, however, it was significantly higher in 20 and $200 \mathrm{mg} / \mathrm{L}$ group only. This effect was elevated after thirty-one days of exposure, followed by minute stabilization and slow decrease till the end (ninety days) of the experiment.

Ramsdorf et al. (2009) observed that the frequencies of MN and nuclear morphological alterations in red blood and kidney cells of Hoplias malabaricus were non significantlydiverse for the intraperitoneal injections of inorganic lead $(21 \mu \mathrm{g}$ and $63 \mu \mathrm{g}$ $\mathrm{Pb}^{2+} / \mathrm{g}$ of body weight) for $96 \mathrm{~h}$ when exposed to 7 , $21,63,100 \mu \mathrm{g} \mathrm{Pb} / \mathrm{g}$ of body weight. Galindo et al. (2010) reported that acute [6, 24, 96h] and subchronic (for fifteen days) exposures of aluminium (1mg Al/L)to Prochilodus lineatus induced a very low and non significant increase in MN frequency while frequency of ENAs (erythrocytic nuclear abnormalities) increased significantly after all the exposure periods. Guner and Muranh (2011) observed generation of MN and NA in peripheral erythrocytes of Gambusia affinis exposed to $0.1 \mathrm{ppm}$ and $1 \mathrm{ppm}$ of $\mathrm{Cu}$ and $0.1 \mathrm{ppm}$ and 1 ppm Cadmium for one and two weeks periods and to $\mathrm{Cu}-\mathrm{Cd}$ combination (0.1 ppm $\mathrm{Cu}+0.1 \mathrm{ppm} \mathrm{Cd}$ ) for two weeks period with a semi-static renewal method. Although $\mathrm{Cu}$ and $\mathrm{Cd}$ did not significantly increase MN occurrence but NA were induced compared to control groups. Rocha et al. (2011) exposed two groups (nine specimens each) of Colosso mamacropomum to $2 \mathrm{mg} / \mathrm{L}$ methylmercury for different periods (group A - 24h; group B $120 \mathrm{~h}$ ) kept third group as negative control (group C) and noticed non significant differences in $\mathrm{MN}$ frequency. For NA, the difference between the frequency of group $B$ and the control group were extremely significant.Exposure of $O$. niloticus to 0.5 and $1.0 \mathrm{mg} / \mathrm{L} \mathrm{Cd}$ (two, four, six and ten days) and $4 \mathrm{mg} / \mathrm{L}$ cyclophosphamide (+ve control) at a regular time period of ten days by Ozkan et al. (2011) resulted in a significant dose dependent increase in MN and NA in the erythrocytes of fish. However, they reported a slow trend of decline initiating from the sixth day,with anon significant difference on the tenth day in comparison to the negative control group. Jindal and Verma (2017) noticed a significant dose and time dependent increase in the frequency of $\mathrm{MN}$ in the gill cells followed by erythrocytes and cephalic kidney in Labeo rohita after treating with cadmium chloride (0.37 and $0.62 \mathrm{mg} \mathrm{l}-1$ ) for a period of $24,48,72$ and $96 \mathrm{~h}$.

\section{Conclusion}

It was concluded that the release of pollutants into the environment constitutes major environmental problems and proved toxic potential due to their capability to induce various toxic, genotoxic, cytotoxic, mutagenic and carcinogenic effects on diverse organisms especially fishes that could have undesirable effects on the environment causing incalculable losses for all aquatic biota indirectly imposing risks to humans. From the data presented here, it can be concluded that the immediate development of chemical compounds free from toxic potential with low toxicity is urgently required. Along with it increased investment in the research aiming at developing effective methods for the biological treatment of effluents so that environment friendly chemicals can be employed in order to reduce the possibility of harmful effects of these compounds on the environment, organisms as well as human health. Such kind of toxicity studies will provide us early indicators for the stress of toxic pollutants which may cause mass mortality of fish in the times to come.

\section{ACKNOWLEDGEMENTS}

Financial support from UGC as Senior Research Fellowship to K Kaur (Vide Letter No. F.40-50(M/ S)/2009(SA-III/MANF) and UPE to A Kaur is greatly acknowledged. 


\section{REFERENCES}

1. Abdel-Moneim, A.M., Abou Shabana, N.M., Khadre, S.E.M. and Abdel-Kader, H.H. (2008). Physiological and histopathological effects in cat fish (Clariaslazera) exposed to dyestufff and chemical waste water. International Journal of Zoological Research 4: 189-202.

2. Allison, G. and Morita, M. (1995). Bioaccumulation and toxic effects of elevated levels of $3,3^{\prime}, 4,4^{\prime}$ tetrachloroazobenzene $\left(3,3^{\prime}, 4,4^{\prime}-\mathrm{TCAB}\right)$ towards aquatic organisms. II: Bioaccumulation and toxic effects of dietary $3,3^{\prime}, 4,4^{\prime}-\mathrm{TCAB}$ on the Japanese Medaka (Oryziaslatipes). Chemosphere 30(2): 223232.

3. Al-Sabti, K. (1991). Handbook of genotoxic effects and fish chromosome. Kristoff, Ljubljana, Slovenia.

4. Al-Sabti, K. (2000). Chlorotriazine reactive Azo red 120 textile dye induces micronuclei in fish. Ecotoxicology and Environmental Safety 47(2): 149-155.

5. Al-Sabti, K., Franko, M., Andrijanic, B., Knez, S. and Stegnar, P. (1994). Chromium induced micronuclei in fish. Journal of Applied Toxicology 14(5): 333-336.

6. Babatunde, T.A. and Aminu, L. (2017). Growth response of juvenile Clarias garieipinus exposed to sublethal concentrations of yogurt factory effluent. Katsina Journal of Natural and Applied Sciences (6):1 (ISSN: 2141-0755).

7. Balakrishnan, V., Asifa, K.P. and Chitra, K.C. (2014). Genotoxic potential of nonylphenol in freshwater fish, Oreochromis mossambicus. International Journal of Applied and Natural Sciences 3: 81-88.

8. Bhunia, F., Saha, N.C. and Kaviraj, A. (2003). Effects of aniline-an aromatic amine to freshwater organisms. Ecotoxicology 12(5): 397-404.

9. Carla, L.G.R., Barbosa, A.C., Ferreira, M.F.N., Dorea, J.G. and Grisolia, C.K. (2008). Evaluation of genotoxicity and effects on reproduction of nonylphenol on Oreochromis niloticus(Pisces: cichlidae). Ecotoxicology 17: 732-737.

10.Cavas, T., Garanko, N.N. and Arkhipchuk, V.V. (2005). Induction of micronuclei and binuclei in blood, gill and liver cells of fishes subchronically exposed to cadmium chloride and copper sulphate. Food and Chemical Toxicology 43: 569-574. doi:10.1016/ j.fct.2004.12.014

11.Fenech, M., Chang, W.P., Kirsch-Volders, M., Holland, N., Bonassi, S. and Zeiger, E. (2003). HUMN project: detailed description of the scoring criteria for the cytokinesis-block micronucleus assay using isolated human lymphocyte cultures. Mutation Research 534: 65-75.

12.Galindo, B.A., Troilo, G., Colus, I.M.S., Martinez, C.B.R. and Sofia, S.H. (2010). Genotoxic Effects of aluminum on the Neotropical Fish Prochiloduslineatus. Water Air and Soil Pollution 212(1): 419-428. doi:10.1007/s11270-010-0357-5

13.Grisolia, C.K. and Cordeiro, C.M.T. (2000). Variability in micronucleus induction with different mutagens applied to several species of fish. Genetics and Molecular Biology 23:235-239.

14.Guner, U. and Muranh, F.D.G. (2011). Micronucleus test, nuclear abnormalities and accumulation of $\mathrm{Cu}$ and $\mathrm{Cd}$ on Gambusia affinis (Baird and Girard, 1853). Turkish Journal of Fisheries and Aquatic Sciences 11: 615-622.

15. Hooftman, R.N. and De Raat, W.K. (1982). Induction of nuclear anomalies (micronuclei) in the peripheral erythrocytes of eastern mud minnow Umbra pygmaea by ethyl methanesulfonate. Mutation Research 104: $147-152$

16.Jindal, R. and Verma, S. (2017). Genotoxicity assessment of cadmium chloride in Labeorohita (Hamilton, 1822) based on induction of micronuclei and other nuclear abnormalities. Indian Journal of Fisheries 64 (Special Issue): 238-242. dOI: 10.21077/ ijf.2017.64.

17.Kaur, H., Kalotra, R., Walia, G.K. and Handa, D. (2013). Dyeing industry effluent induced behavioural and morphological changes in the fish,Cirrhinus mrigala. International Journal of Zoology and Research3: 13-20.

18.Kaur, R. and Dua, A. (2014). Acute toxicity, behavioural and morphological alterations in Indian Carp, Labeorohita Ham., on exposure to municipal wastewater of Tung Dhab Drain, Punjab, India. International Journal of Science and Research 3: 17161720.

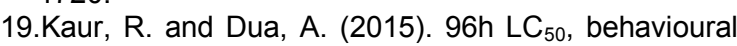
alterations and histopathological effects due to wastewater toxicity in a freshwater fish Channa punctatus. Environmental Science and Pollution Research 22: $5100-5110$.

20.Kaur, R. and Dua, A. (2016). Fish liver and gill cells as cytogenotoxic indicators in assessment of water quality. Environmental Science and Pollution Research 23: 18892-900.

21.Kundu, R., Prasad, V.V.S. and Mansuri, A.P. (1989). Toxicity of diluted dyeing and printing industry effluent to a panaeid Prawn Parapenaeopsissculptilis. Acta Hydrochimica et Hydrobiologica17(1): 1-6.

22.Malla, T.M., Senthikumar, C.S., Akhtar, S. and Ganesh, N. (2011). Micronuclei as an evidence of DNA damage in fresh water cat fish Heteropneustesfossilis (Bloch) exposed to synthetic sindoor. Journal of Agricultural and Biological Science 6: 4144

23.Manjunatha, B. Wei-Bing, P., Ke-Chun, L., Marigoudar, S.R., Xi-Qiang, C., Xi-Min, W., Xue, W. (2014). The effects of henna (hair dye) on the embryonic development of zebrafish (Danio rerio). Environmental Science and Pollution Research21: 1036110367. doi: 10.1007/s11356-014-2968-7.

24.Market, B.A., Breure, A.M., Zechmeister, H.G. (2003). Bioindicators and biomonitoring principles, concepts and applications. Elsevier, Oxford, UK.

25.Marlasca, M.J., Valles, B., Riva, M.C. and Crespo, S. (1992). Sublethal effects of synthetic dyes on rainbow trout Oncorhynchus mykiss: a light and electron microscope study. Diseases of aquatic organisms 12: 103-110.

26.Mathur, N., Bhatnagar, P., Nagar, P. and Bijarnia, M.K. (2005). Mutagenicity assessment of from textile/ dye industries of Sanganer, Jaipur (India): a case study. Ecotoxicology and Environmental Safety 61: 105-113.

27.McCarthy, B. (1997). Biotechnology and Coloration. Review of Progress in Coloration 27: 26-31.

28.Mishra, A., Tripathi, C.P.M., Dwivedi, A.K. and Dubey, V.K. (2011). Acute toxicity and behavioral response of freshwater fish, Mystusvittatus exposed to pulp mill effluent. Journal of Environmental Chemistry and Ecotoxicology 3: 167-172.

29.Muley, D.V., Karanjkar, D.M. and Maske, S.V. (2007). Impact of industrial effluents on the biochemi- 
cal composition of freshwater fish Labeorohita. Journal of Environmental Biology 28: 245-249.

30.Nepomuceno, J.C., Ferrari, I.,Spanó, M.A. and Centeno, A.J. (1997). Detection of micronuclei in peripheral erythrocytes of Cyprinus carpio exposed to metallic mercury. Environmental and Molecular Mutagenesis 30(3): 293-297. https://doi.org/10.1002/ (SICI)1098-2280(1997)30:3<293::AID-

EM7>3.0.CO;2-M

31.Normann, C.A.B.M., Moreira, J.C.F. and Cardoso, V.V. (2008). Micronuclei in red blood cells of armored catfish Hypostomus plectomus exposed to potassium dichromate. African Journal of Biotechnology 7(7): 893-896.

32.Ogali, R.E., Osuji, L.C. and Ayodele, O. (2007). Acute toxicity of the water-soluble fraction of spent lubricating oil on the African catfish (Clarias gariepinus). Chemistry and Biodiversity 4: 2755-2765.

33.Olubukola, A.A. and Victor, C.A. (2012). Altered reproduction in Clariasgariepinus exposed to industrial effluents. American Journal of Agricultural and Biological Sciences 7: 61-70.

34.Osman, A.G.M. (2014). Genotoxicity tests and their contributions in aquatic environmental research. Journal of Environmental Protection 5: 1391-1399.

35.Ozkan, F., Gunduz, S.G., Berkoz, M. and Hunt, A.O. (2011). Induction of micronuclei and other nuclear abnormalities in peripheral erythrocytes of Nile tilapia, Oreochromis niloticus, following exposure to sublethal cadmium doses. Turkish Journal of Zoology 35 (4): 585-592.

36.Palhares, D. and Grisolia, C.K. (2002). Comparison between the micronucleus frequencies of kidney and gill erythrocytes in tilapia fish, following mitomycin c treatment. Genetics and Molecular Biology 25(3): 281-284.

37.Pathan, T.S., Sonawane, D.L. and Khillare, Y.K. (2009). Toxicity and behavioral changes in freshwater fish, Rasbora daniconius exposed to paper mill effluent. Botany Research International 2:263-266.

38.Raizada, S. and Rana, K.S. (1998). Acute toxicity of malachite green to an air breathing teleost, Clarias batrachus. Journal of Environmental Biology 19(3): 237-241

39.Ramsdorf, W.A., Ferraro, M.V.M., Oliveira-Ribeiro, Costa, J.R.M. and Cestari, M.M. (2009). Genotoxic evaluation of different doses of inorganic lead (Pbll) in Hoplias malabaricus. Environmental Monitoring and Assessment 158: 77-85 doi: 10.1007/s10661008-0566-1

40.Rana, K.S. and Raizada, S. (1999). Acute toxicity of tannery and textile dye effluents on a common teleost, Labeo rohita: Histological alterations in liver. Journal of Environmental Biology 20(1): 33-36.

41.Reeves, J.F., Davies, S.J., Dodd, N.J.F. and Jha, A.N. (2008). Hydroxyl radicals $(\mathrm{OH})$ are associated with titanium dioxide $\left(\mathrm{TiO}_{2}\right)$ nanoparticle-induced cytotoxicity and oxidative DNA damage in fish cells. Mutation Research-Fundamentals and Molecular mechanisms of Mutagenesis 640: 113-122. doi: 10.1016/j.mrfmmm.2007.12.010.

42.Riva, M.C. (1989). Toxicidad, accumulation y efectos fisiologicos del colorante premetabilizado C.I. acid violet 66 y su base azoica C. I. acid red 217 en la trucha arcoiris Salmo gairdneri R. Ph.D. Thesis, UniversitatAutonoma de Barcelona.

43.Rocha, C.A.M., Cunha, L.A., Silva, R.H., Bahia, M.O. and Burbano, R.M.R. (2011). Studies of micronuclei and other nuclear abnormalities in red blood cells of Colossomamacropomum exposed to methyl mercury. Genetics and Molecular Biology 34(4): 694-697.

44.Rocha, C.A.M., Gomes, C.F., Junior, R.F.G.R. and Pinheiro, R.H.S. (2011). Detection of micronuclei and other nuclear abnormalities in Oreochromis niloticus exposed to potassium dichromate. Global Veterinaria7: $301-304$

45.Sani, Z.M., Abdullahi, I.L. and Sani, A. (2018). Toxicity Evaluation of Selected Dyes Commonly used for Clothing Materials in Urban Kano, Nigeria. European Journal of Experimental Biology 8(4):26.

46.Selvaraj, D., Leena, R., Kamal, D.C. (2015) Toxicological and histopathological impacts of textile dyeing industry effluent on a selected teleost fish Poecilia reticulata. Asian Journal of Pharmacology and Toxicology 3: 26-30.

47.Sharma, S., Sharma, S.and Sharma, K.P. (2005). Protective role of Spirulina feed in a freshwater fish (Poecilia reticulate Peters) exposed to an azo dyemethyl red. Indian Journal of Experimental Biology43 (12): 1165-1169.

48.Srivastava, S., Sinha, R. and Roy, D. (2004). Toxicological effects of malachite green. Aquatic Toxicology66(3): 319-329. This article is not included in your organization's subscription. However, you may be able to access this article under your organization's agreement with Elsevier.

49.Srivastava, S.J., Singh, N.D., Srivastava, A.K. and Sinha, R. (1995). Acute toxicity of malachite green and its effect on certain blood parameters of a cat fish Heteropneustes fossils. Aquatic Toxicology31: 241-7.

50.Talykina, M.G., Papoulias, D.M. and Allert, J.A., Izyuov, Y.U., Villalobos, S.A., Giesy, J.P. and Tillitt, D.E. (2003). The effect of polychlorinated napthalenes and tributyllin on the occurrence of aberrant nuclei in Erythroid cells of Medaka. Environmental Sciences 10(6): 337-348.

51.Tchounwou, P.B., Yedjou, C.G., Patlolla, A.K. and Sutton, D.J. (2012). Heavy Metals Toxicity and the Environment. Molecular, Clinical and Environmental Toxicology101: 133-164.

52.Tlili, S., Jebali, J., Banni, M., Haouas, Z., Mlayah, A., Helal, A.N. and Boussetta, H. (2009). Multimarker approach analysis in common carp Cyprinus carp sampled from three freshwater sites. Environmental Monitoring and Assessment 168(1-4): 285-298.

53.Tonogai, Y., Ito, Y., Iwaida, M., Tati, M., Ose, Y. and Hori, M. (1979). Studies on the toxicity of coal-tar dyes II. The Journal of Toxicological Sciences4(3): 211-219.

54.Ukagwu, J.I., Onuoha, G.U.C. and Chude, L.A. (2012). Acute toxicity of pulp and paper mill effluent to the survival of juvenile catfish (Clariasgariepinus) under laboratory condition. Nigerian Journal of Agriculture, Food and Environment 8: 73-78.

55.Varadaraj, G. and Subramanian, M.A. (1991). Toxic effect of paper and pulp mill effluent on different parameters of bioenergetics in the fingerlings of Oreochromis mossambicus. Journal of Environment and Ecology9(4):857-859

56.White, C.R., Davies, S.J. Henry, T.B. (2012). Malachite green toxicity and effects on reproductive success in zebrafish Danio rerio. Zebrafish9(3): 135-9. doi: 10.1089/zeb.2012.0762. 